\title{
Sustained release of anticancer agent phytic acid from its chitosan-coated magnetic nanoparticles for drug-delivery system
}

This article was published in the following Dove Press journal:

International Journal of Nanomedicine

27 March 2017

Number of times this article has been viewed

\author{
Farahnaz Barahuie ${ }^{1,2}$ \\ Dena Dorniani ${ }^{1,3, *}$ \\ Bullo Saifullah',* \\ Sivapragasam Gothai ${ }^{4}$ \\ Mohd Zobir Hussein' \\ Ashok Kumar Pandurangan ${ }^{5}$ \\ Palanisamy Arulselvan ${ }^{4}$ \\ Mohd Esa Norhaizan ${ }^{6}$ \\ 'Materials Synthesis and \\ Characterization Laboratory, Institute \\ of Advanced Technology, Universiti \\ Putra Malaysia, Serdang, Selangor, \\ Malaysia; ${ }^{2}$ Zabol University of Medical \\ Sciences, Zabol, Iran; ${ }^{3}$ Department \\ of Chemistry, University of Sheffield, \\ Sheffield, UK; ${ }^{4}$ Laboratory of Vaccines \\ and Immunotherapeutics, Institute \\ of Bioscience, Universiti Putra \\ Malaysia, Serdang, Selangor, Malaysia; \\ ${ }^{5}$ Department of Pharmacology, Faculty \\ of Medicine, University of Malaya, \\ Kuala Lumpur, Malaysia; ${ }^{6}$ Department \\ of Nutrition and Dietetics, Faculty \\ of Medicine and Health Sciences, \\ Universiti Putra Malaysia, Serdang, \\ Selangor, Malaysia \\ *These authors contributed equally \\ to this work
}

Correspondence: Mohd Esa Norhaizan Department of Nutrition and Dietetics, Faculty of Medicine and Health Sciences, Universiti Putra Malaysia, 43400 Serdang, Selangor, Malaysia

Tel +60 389472427

Fax +60389426769

Email nhaizan@upm.edu.my
Abstract: Chitosan (CS) iron oxide magnetic nanoparticles (MNPs) were coated with phytic acid (PTA) to form phytic acid-chitosan-iron oxide nanocomposite (PTA-CS-MNP). The obtained nanocomposite and nanocarrier were characterized by powder X-ray diffraction, Fourier transform infrared spectroscopy, vibrating sample magnetometry, transmission electron microscopy, and thermogravimetric and differential thermogravimetric analyses. Fourier transform infrared spectra and thermal analysis of MNPs and PTA-CS-MNP nanocomposite confirmed the binding of CS on the surface of MNPs and the loading of PTA in the PTA-CS-MNP nanocomposite. The coating process enhanced the thermal stability of the anticancer nanocomposite obtained. X-ray diffraction results showed that the MNPs and PTA-CS-MNP nanocomposite are pure magnetite. Drug loading was estimated using ultraviolet-visible spectroscopy and showing a $12.9 \%$ in the designed nanocomposite. Magnetization curves demonstrated that the synthesized MNPs and nanocomposite were superparamagnetic with saturation magnetizations of $53.25 \mathrm{emu} / \mathrm{g}$ and $42.15 \mathrm{emu} / \mathrm{g}$, respectively. The release study showed that around $86 \%$ and $93 \%$ of PTA from PTA-CS-MNP nanocomposite could be released within 127 and 56 hours by a phosphate buffer solution at pH 7.4 and 4.8, respectively, in a sustained manner and governed by pseudosecond order kinetic model. The cytotoxicity of the compounds on HT-29 colon cancer cells was evaluated by 3-(4,5-dimethylthiazol-2-yl)-2,5-diphenyltetrazolium bromide assay. The HT-29 cell line was more sensitive against PTA-CS-MNP nanocomposite than PTA alone. No cytotoxic effect was observed on normal cells (3T3 fibroblast cells). This result indicates that PTA-CS-MNP nanocomposite can inhibit the proliferation of colon cancer cells without causing any harm to normal cell.

Keywords: nanocomposite, drug delivery, chitosan, phytic acid, HT-29 cell line, controlled release

\section{Introduction}

Nanotechnology has incredible potential for revolutionizing the medical world by developing personalized medicine both for diagnosis and therapy. Nanomedicine (nanosized therapeutics and imaging agents) has exhibited a strong growth in nanodrugs where designed ingenious biocompatible nanocomposites for drug delivery purposes. These nanocomposites are widely used as nanodelivery systems that enhance the biodistribution of drugs and selectively target diseased tissues while protecting healthy tissues. ${ }^{1,2}$

Various nanocarriers including liposomes, ${ }^{3-6}$ cell-based nanocarriers, ${ }^{7}$ polymers, ${ }^{8}$ carbon materials, ${ }^{9,10}$ dendrimers, ${ }^{11}$ and inorganic nanoparticles ${ }^{12,13}$ have been employed for gene and drug delivery systems, which have shown efficacy both in vitro and in vivo. Recently, much attention has been devoted to polymer-based nanoparticles (typically chitosan [CS]-iron 
oxide nanoparticles) as novel cellular delivery vectors in cancer therapy because of their excellent properties such as high encapsulation efficiency, sustained release properties, effective and convenient routes of administration, less toxicity, endocytosis efficiency, surface modifying capacity, ability to differentiate between cancer and normal cells, ${ }^{14}$ superparamagnetic behavior and contrast agent, and low health care cost. ${ }^{15}$

Iron oxide magnetic nanoparticles (MNPs) with general formula $\mathrm{Fe}_{3} \mathrm{O}_{4}$ have been widely used for delivery of various drugs owing to some advantages: ease of preparation, superparamagnetic property, ${ }^{16-18}$ biocompatibility, external control, controllable parameters, ${ }^{19,20}$ and hypothermal behavior. $^{21,22}$ However, these nanoparticles due to the presence of $\mathrm{OH}^{-}$groups with a large surface area to volume ratio and dipole-dipole attraction without any surface coating will be agglomerated and the size of particles will increase. Therefore, it is necessary to use polymers in the coating process to prevent the nuclear growth of iron oxide, preclude nanoparticles aggregation, and reduce toxic effect. ${ }^{23-25}$

$\mathrm{CS}$, a natural polymer and deacetylated derivative of chitin, is most commonly used as a coating material for nanoparticles in anticancer drug delivery systems because of its unique biological features including biocompatibility, ${ }^{26}$ anti-carcinogenicity, biodegradability, nontoxicity, hydrophilicity, ,3,27-29 $^{2}$ and great antimicrobial property. ${ }^{30}$ The CS polymer reacts with iron oxide nanoparticles through glycosidic bonds and improves the stability and chemical reactivity of nanoparticles. ${ }^{31}$

Extensive studies using CS-MNPs nanocarrier have been performed in recent years to enhance anticancer drug efficacy and reduce the side effects of the drug. For instance, Javid et $\mathrm{al}^{32}$ demonstrated that CS-MNPs nanoreservoir with a higher drug loading capacity increased the drug efficiency and anticancer properties of doxorubicin. The results emphasized that doxorubicin-CS-MNP nanocomposite showed a greater growth inhibitory effect on ovarian cancer cells (A2780 and OVCAR-3) than free drug. ${ }^{32}$

Phytic acid (PTA; $\mathrm{C}_{6} \mathrm{H}_{18} \mathrm{O}_{24} \mathrm{P}_{6}$ ) is a natural compound discovered in 1903. It is the major storage form of phosphorous in plants and legumes, including wheat bran, corn, soy beans, rice bran, and nuts, ${ }^{33}$ and it is reported to possess a broad range of pharmaceutical properties, such as antioxidant, ${ }^{34,35}$ chemopreventive, ${ }^{36,37}$ hepatoprotective, and anticancer properties. Many studies presented that PTA inhibited cancer cell growth in leukemia, prostate, breast, liver, colon, and skin cancers. ${ }^{38-40}$ However, this anticancer drug has very short plasma half-life and is released very fast.

Therefore, considering the aforementioned advantages of CS-MNPs, we report here the synthesis of a new nanohybrid, phytic acid-chitosan-MNPs (PTA-CS-MNP). The objective of this research was to explore the potential use of CS-MNPs for the delivery of anticancer drug PTA. We investigated the sustained release behavior of PTA from CS-MNPs nanocarrier and evaluated the cytotoxic effects against cancer cells and normal fibroblast (3T3) cell lines in vitro.

\section{Materials and methods Materials}

The chemicals in this study were of analytical grade and were used as received without further purification. PTA sodium salt from rice (molecular formula: $\mathrm{C}_{6} \mathrm{H}_{18} \mathrm{O}_{24} \mathrm{P}_{6} \mathrm{xNa}^{+} \cdot \mathrm{yH}_{2} \mathrm{O}$; molecular weight: 660.04) with $\geq 90$ purity and CS, deacetylated at $75 \%-85 \%$, sodium amp salt ( $>98 \%$ purity; molecular weight: $371.4 \mathrm{~g} / \mathrm{mol}$ ) were acquired from Sigma-Aldrich ( $\mathrm{St}$ Louis, MO, USA). Aqueous acetic acid solution (99.8\%) was supplied by Hamburg Industries (Hamburg, Germany). Ferrous chloride tetrahydrate $\left(\mathrm{FeCl}_{2} \cdot 4 \mathrm{H}_{2} \mathrm{O}, \geq 99 \%\right.$ purity) and ferric chloride hexahydrate $\left(\mathrm{FeCl}_{3} \cdot 6 \mathrm{H}_{2} \mathrm{O}, \geq 99 \%\right.$ purity) were obtained from Merck KGaA (Darmstadt, Germany). Ammonia solution (25\%) was purchased from Scharlau (Sentmenat, Barcelona, Spain). Deionized water was used in each experiment.

\section{Synthesis of MNPs}

The MNPs were prepared by a coprecipitation method as previously reported. ${ }^{41}$ They were prepared by mixing solutions of $2.43 \mathrm{~g}$ of ferrous chloride tetrahydrate $\left(\mathrm{FeCl}_{2} \cdot 4 \mathrm{H}_{2} \mathrm{O}\right), 0.99 \mathrm{~g}$ ferric chloride hexahydrate $\left(\mathrm{FeCl}_{3} \cdot 6 \mathrm{H}_{2} \mathrm{O}\right)$, and $80 \mathrm{~mL}$ of deionized water in the presence of $6 \mathrm{~mL}$ of ammonia $(25 \%$ by mass). The $\mathrm{pH}$ value of the solution was maintained at 10 . Then the mixture was sonicated for 1 hour at room temperature. Finally, the precipitate was centrifuged and washed three times with deionized water.

\section{Synthesis of CS-MNPs}

The solution of CS was prepared by dissolving $1 \mathrm{~g}$ of CS powder in $1 \%$ acetic acid solution. It was followed by the addition of CS solution to MNPs suspension and then the mixture was stirred for 18 hours at room temperature. The obtained mixture was centrifuged and washed three times with deionized water and dried at $70^{\circ} \mathrm{C}$. The product was labeled CS-MNPs. ${ }^{23}$

\section{Synthesis of PTA-CS-MNP nanocomposite}

The PTA-CS-MNP nanocomposite was obtained by mixing PTA sodium salt solution (2 g in $100 \mathrm{~mL}$ deionized water) 
with a known amount of CS-MNPs. The solution was then kept under vigorous stirring for 24 hours. The final slurry was centrifuged, washed, and finally dried at $60^{\circ} \mathrm{C}$ oven.

\section{Characterization of PTA-CS-MNP nanocomposite}

The magnetic property of the samples was evaluated using Lake Shore 7404 vibrating sample magnetometer (Lake Shore Cryotronics, Inc., Westerville, OH, USA). The thermal analyses of the materials were performed using Mettler Toledo thermogravimetric (TGA) and differential thermogravimetric (DTG) instruments with a heating rate of $10^{\circ} \mathrm{C}$ per minute at temperature $20^{\circ} \mathrm{C}-1,000^{\circ} \mathrm{C}$ under nitrogen atmosphere ( $\mathrm{N}_{2}$ flow rate $50 \mathrm{~mL}$ per minute). Powder X-ray diffraction (PXRD) patterns were used to determine the crystal structures of the samples over a range of $5^{\circ}-70^{\circ}$, using an XRD-6000 diffractometer (Shimadzu, Tokyo, Japan) with $\mathrm{CuK} \alpha$ radiation $(\lambda=1.5406 \AA)$ at $30 \mathrm{kV}$ and $30 \mathrm{~mA}$. Fourier transform infrared (FTIR) spectra of the materials were recorded over a range of 400-4,000 $\mathrm{cm}^{-1}$, using a Nexus, Smart Orbit spectrometer (Thermo Fisher Scientific, Waltham, MA, USA) and $\mathrm{KBr}$ disk method. The ultraviolet-visible (UV-Vis) spectrophotometer (Shimadzu 1650 series; Shimadzu) was used to determine the optical and controlled-release properties of PTA from PTA-CS-MNP nanocomposite. The mean particle size and size distribution were determined using a transmission electron microscope (Hitachi H-7100; Hitachi, Tokyo, Japan) at an accelerating voltage of 80 and $200 \mathrm{kV}$.

\section{Loading and release of PTA from PTA-CS-MNP nanocomposite}

The percentage of PTA loading in PTA-CS-MNP nanocomposite was measured using UV-Vis spectrophotometer (Shimadzu 1650 series; Shimadzu) and calibration curve equation. Approximately $5 \mathrm{mg}$ of the nanocomposite was dissolved in concentrated $\mathrm{HCl} / \mathrm{HNO}_{3}$. In this condition $100 \%$ PTA content would be released from the nanocomposite. The amount of PTA released was measured by UV-Vis spectroscopy at a wavelength of $275 \mathrm{~nm}$ and using calibration curves.

PTA release profiles from the nanocomposite were determined at room temperature using $0.01 \mathrm{M}$ phosphate-buffered saline (PBS) solution at $\mathrm{pH} 4.8$ and 7.4. A total of $85 \mathrm{mg}$ of PTA-CS-MNP nanocomposite was added to $500 \mathrm{~mL}$ of PBS medium. The cumulative amount of PTA released into the solution was measured at predetermined time intervals at $\lambda_{\text {max }}=275 \mathrm{~nm}$ using a UV-Vis spectrophotometer. The release rate of PTA from PTA-CS-MNP nanocomposite was compared with that from physical mixture that contained PTA sodium salt, CS, and MNPs.

\section{Cytotoxicity assay of PTA-CS-MNP nanocomposite}

HT-29 and 3T3 cells were obtained from American Type Culture Collection (ATCC, VA, USA), and these cells were cultured and plated at a density of $1 \times 10^{4}$ cells by adding $100 \mu \mathrm{L}$ of cell suspension to each well of a 96-well tissue culture plate. The plates were incubated for sufficient time to ensure attachment of cells. The growth rate was $\sim 70 \%-80 \%$ confluency. The media were aspirated off and replaced with fresh media $(100 \mu \mathrm{L})$ containing different concentrations of PTA-CS-MNP nanocomposite as well as pure compound, PTA $(25-500 \mu \mathrm{g} / \mathrm{mL})$. The treated plates were incubated at $37^{\circ} \mathrm{C}$ in $5 \% \mathrm{CO}_{2}$ for 72 hours with appropriate control. After incubation with the compounds, 3-(4,5-dimethylthiazol2-yl)-2,5-diphenyltetrazolium bromide (MTT) solution $(5 \mathrm{mg} / \mathrm{mL}$ ) in a total volume of $10 \mu \mathrm{L}$ was added to every well and mixed gently with the media, which was later incubated for 4 hours at $37^{\circ} \mathrm{C}$ in $5 \% \mathrm{CO}_{2}$. The MTT solution containing the medium was then removed carefully and replaced with dimethyl sulfoxide (DMSO) $(100 \mu \mathrm{L}$ per well) to dissolve the formazan crystals. Finally, the culture plates were read in a microplate reader at $570 \mathrm{~nm}$. The concentration of drug needed to inhibit cell growth by $50 \%\left(\mathrm{IC}_{50}\right)$ was generated from the dose-response curves for each compound and each cell line.

\section{Results and discussion PXRD}

Figure 1A-C illustrates the PXRD patterns of the MNPs, PTA-CS-MNP, and PTA sodium salt, respectively. For MNPs and PTA-CS-MNP nanocomposite, six characteristic peaks at $2 \theta=30.2^{\circ}, 35.5^{\circ}, 43.2^{\circ}, 53.5^{\circ}, 57.2^{\circ}$, and $62.7^{\circ}$ were indexed to (220), (311), (400), (422), (511), and (440), respectively, (JCPDS No 19-629) which are due to the cubic spinel structure of pure $\mathrm{Fe}_{3} \mathrm{O}_{4} \cdot{ }^{42}$ Figure $1 \mathrm{~A}$ and $\mathrm{B}$ reveals that the coating process did not affect the phase change of MNPs as there is no changes in the position of the peaks. ${ }^{43}$ However, the coating process resulted in a lower peak intensity and crystallinity of the PTA-CS-MNP nanocomposite. The mean grain size was calculated from XRD data by Debye-Scherrer equation that determines the connection between average particle size and peak broadening in XRD.

$$
\mathrm{D}=\frac{\mathrm{K} \lambda}{\beta \cos \theta}
$$

where $\mathrm{D}$ is the average particle size, $\mathrm{K}$ is the Debye-Scherrer constant (0.89), $\lambda$ is the $\mathrm{X}$-ray wavelength $(0.15406 \mathrm{~nm})$, 


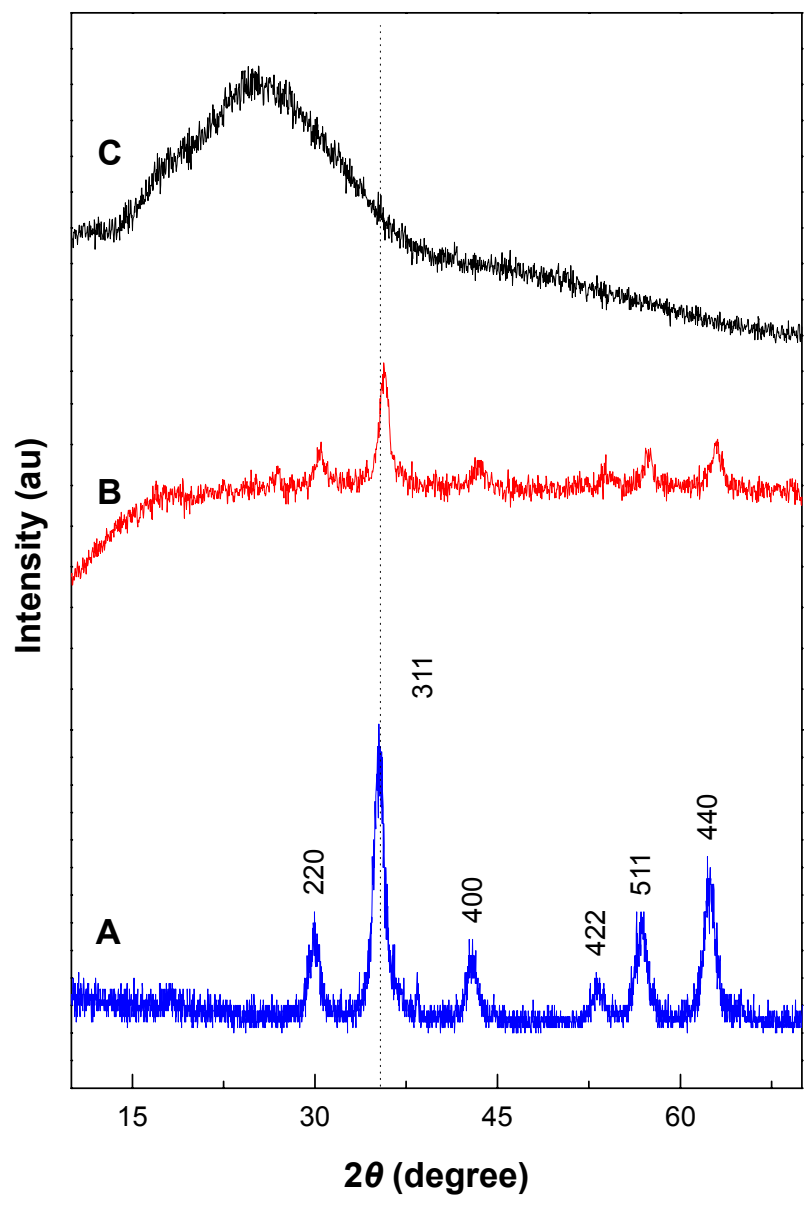

Figure I Powder X-ray diffraction patterns of iron oxide magnetic nanoparticles (A), PTA-CS-MNP nanocomposite (B), and phytic acid sodium salt (C).

Abbreviation: PTA-CS-MNP, phytic acid-chitosan-iron oxide nanocomposite.

$\beta$ is the peak width of half-maximum, and $\theta$ is the diffraction angle. The mean particle size of MNPs obtained from this equation was $\sim 8 \mathrm{~nm}$.

\section{FTIR spectroscopy}

The FTIR spectra of MNPs, PTA-CS-MNP nanocomposite, and PTA sodium salt are presented in Figure 2. The MNPs in Figure 2A shows an absorption peak at $569 \mathrm{~cm}^{-1}$ that is due to the stretching of $\mathrm{Fe}-\mathrm{O}$ in $\mathrm{Fe}_{3} \mathrm{O}_{4}$. However, this peak was shifted to $565 \mathrm{~cm}^{-1}$ in the PTA-CS-MNP nanocomposite (Figure 2B), which confirm the presence of MNPs in the nanocomposites. ${ }^{44}$ The broad absorption peak observed at 3,415 $\mathrm{cm}^{-1}$ in Figure 2A is ascribed to the $\mathrm{O}-\mathrm{H}$ stretching. In the PTA-CS-MNP nanocomposite spectra (Figure 2B), the characteristic band for CS was observed at $1,560 \mathrm{~cm}^{-1}$, which proves that MNPs were successfully coated with $\mathrm{CS}^{45}$

The FTIR spectra of PTA sodium salt shown in Figure 2C displays some intense, sharp absorption peaks due

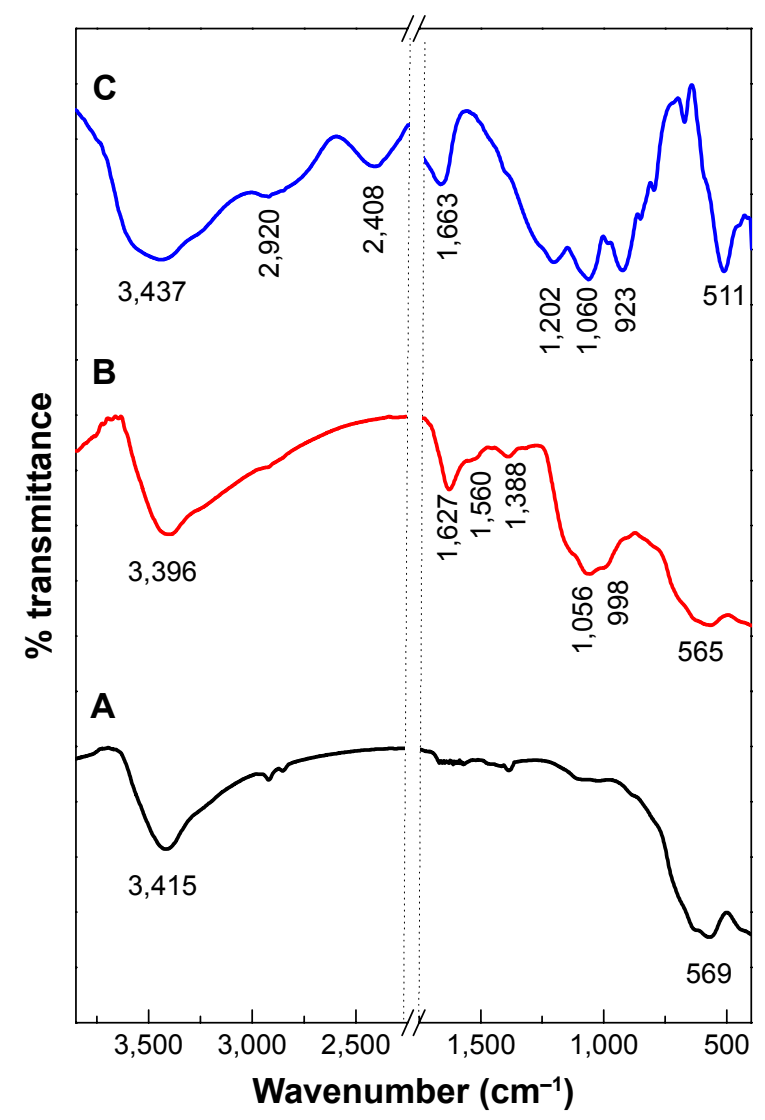

Figure 2 Fourier transform infrared spectra of iron oxide magnetic nanoparticles (A), PTA-CS-MNP nanocomposite (B), and phytic acid sodium salt (C).

Abbreviation: PTA-CS-MNP, phytic acid-chitosan-iron oxide nanocomposite.

to different functional groups in the molecules. The characteristic bands at 1,202 and $1,060 \mathrm{~cm}^{-1}$ can be assigned to the stretching vibration of $\mathrm{P}=\mathrm{O}$ and $\mathrm{P}-\mathrm{O}-\mathrm{C}$, respectively, and in the nanocomposite spectrum (Figure 2B), the bands shifted to 1,388 and $1,056 \mathrm{~cm}^{-1}$, respectively, due to coating process. The stretch at $511 \mathrm{~cm}^{-1}$ corresponded to the $\mathrm{O}-\mathrm{Na}$ and $\mathrm{O}-\mathrm{P}=\mathrm{O}$ vibrations were revealed at 2,408 and 2,920 $\mathrm{cm}^{-1}$ (Figure 2C). ${ }^{46}$ The absorption peaks of $\mathrm{OH}$ group of water molecules present in the PTA sodium salt appeared at 1,663 and $3,437 \mathrm{~cm}^{-1}$, ${ }^{46}$ while the peaks were recorded at 1,627 and $3,396 \mathrm{~cm}^{-1}$ in the nanocomposite spectra (Figure 2B).

Figure 3 shows the interaction between the MNPs, $\mathrm{CS}$, and PTA. It is clear that MNPs interacted with CS through glycosidic bonds (Figure 3A), whereas PTA (Figure 3B) interacted with CS polymer through hydrogen bonds. $^{47,48}$

\section{Thermal analysis}

The thermal behavior of PTA sodium salt, MNPs, and PTACS-MNP nanocomposite was examined by TGA and DTG 


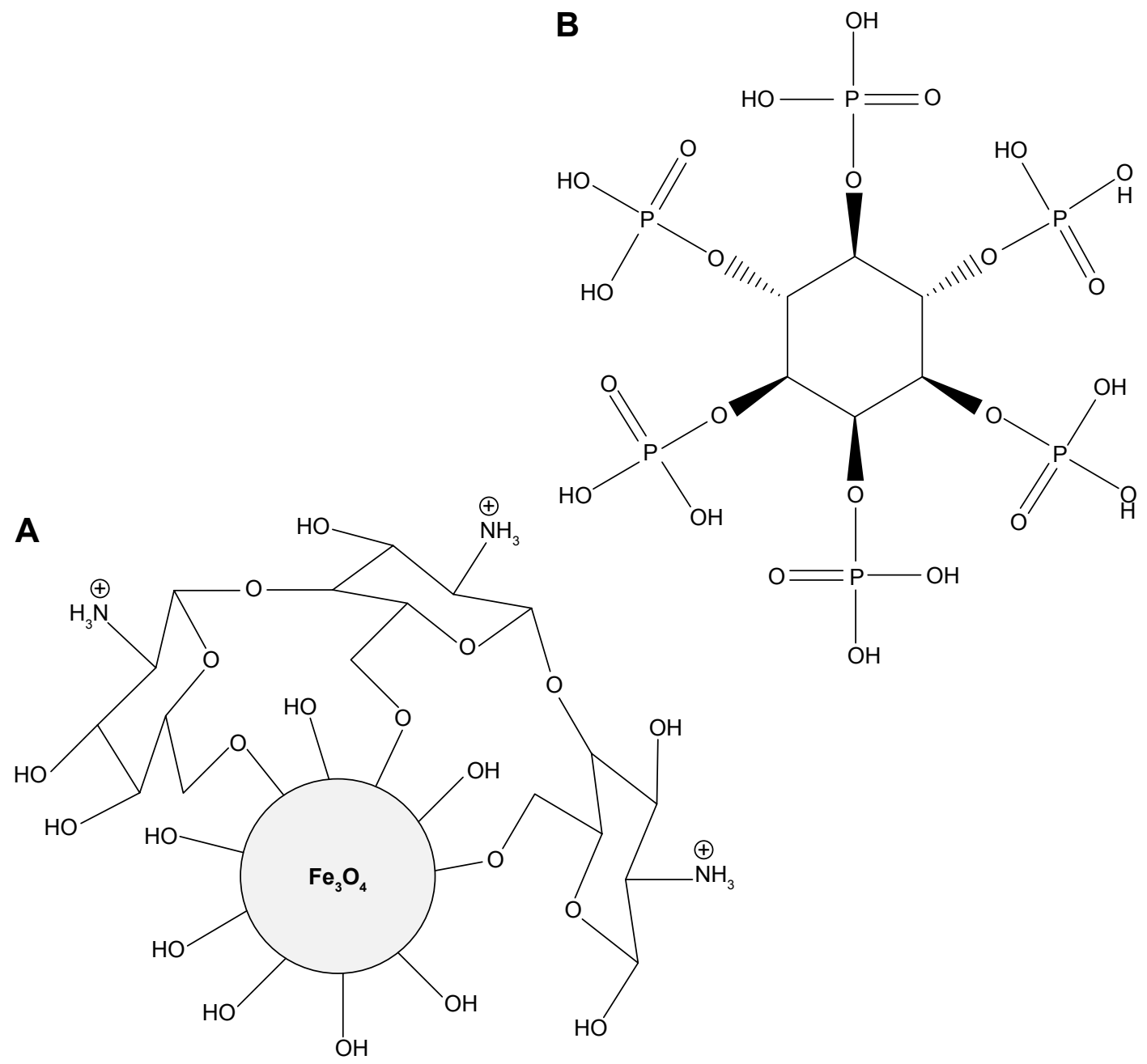

Figure 3 Schematic representation of the interaction between iron oxide magnetic nanoparticles, chitosan (A), and phytic acid (B) in the PTA-CS-MNP nanocomposite. Abbreviation: PTA-CS-MNP, phytic acid-chitosan-iron oxide nanocomposite.

analyses (Figure 4). The PTA sodium salt thermal decomposition (Figure 4A) showed three weight loss events. The first event occurred at $123^{\circ} \mathrm{C}$ with a weight loss of $25.9 \%$, which was due to the removal of water present in the sample. The second weight loss of $20.6 \%$ at $205^{\circ} \mathrm{C}$ might be due to the carbonization process and dehydration that takes place due to the decomposition of $\mathrm{OH}$ groups. This third one was followed by the decomposition of phytate groups and the elimination of elemental carbon formed in the previous step at $309^{\circ} \mathrm{C}$ with a mass reduction of $41.2 \%{ }^{49}$ The TGA/DTG thermograms of MNPs (Figure 4B) exhibited a single-stage mass reduction at $44^{\circ} \mathrm{C}$ with a weight loss of $9.7 \%$, which can be attributed to the loss of surface hydroxyl groups and residual water. ${ }^{25}$ For PTA-CS-MNP nanocomposite, three main thermal phenomena were observed (Figure 4C). The first weight loss of $9.6 \%$ at $62^{\circ} \mathrm{C}$ was related to the removal of surface physisorbed water molecules. The second and third weight loses of $23.4 \%$ and $12.1 \%$ at $242^{\circ} \mathrm{C}$ and $610^{\circ} \mathrm{C}$, respectively, corresponded to the decomposition of PTA and CS biopolymer. The temperature region of the nanocomposite appeared to be clearly higher than that of the free drug due to the electrostatic attraction between the MNPs, $\mathrm{CS}$, and PTA.

\section{Magnetic properties}

Superparamagnetism is an essential and important property for magnetic-targeting carriers in drug-delivery system. ${ }^{50}$ Magnetic properties of MNPs and PTA-CS-MNP nanocomposite were characterized by vibrating sample magnetometer as a function of the magnetic field at room temperature (Figure 5). The saturation magnetization of MNPs was $53.25 \mathrm{emu} / \mathrm{g}$ compared to that of PTA-CS-MNP nanocomposite which was $42.15 \mathrm{emu} / \mathrm{g}$, and negligible coercivity and remanent magnetization were observed for both samples, which confirmed the superparamagnetic properties of the samples. The decrease in saturation magnetization of 

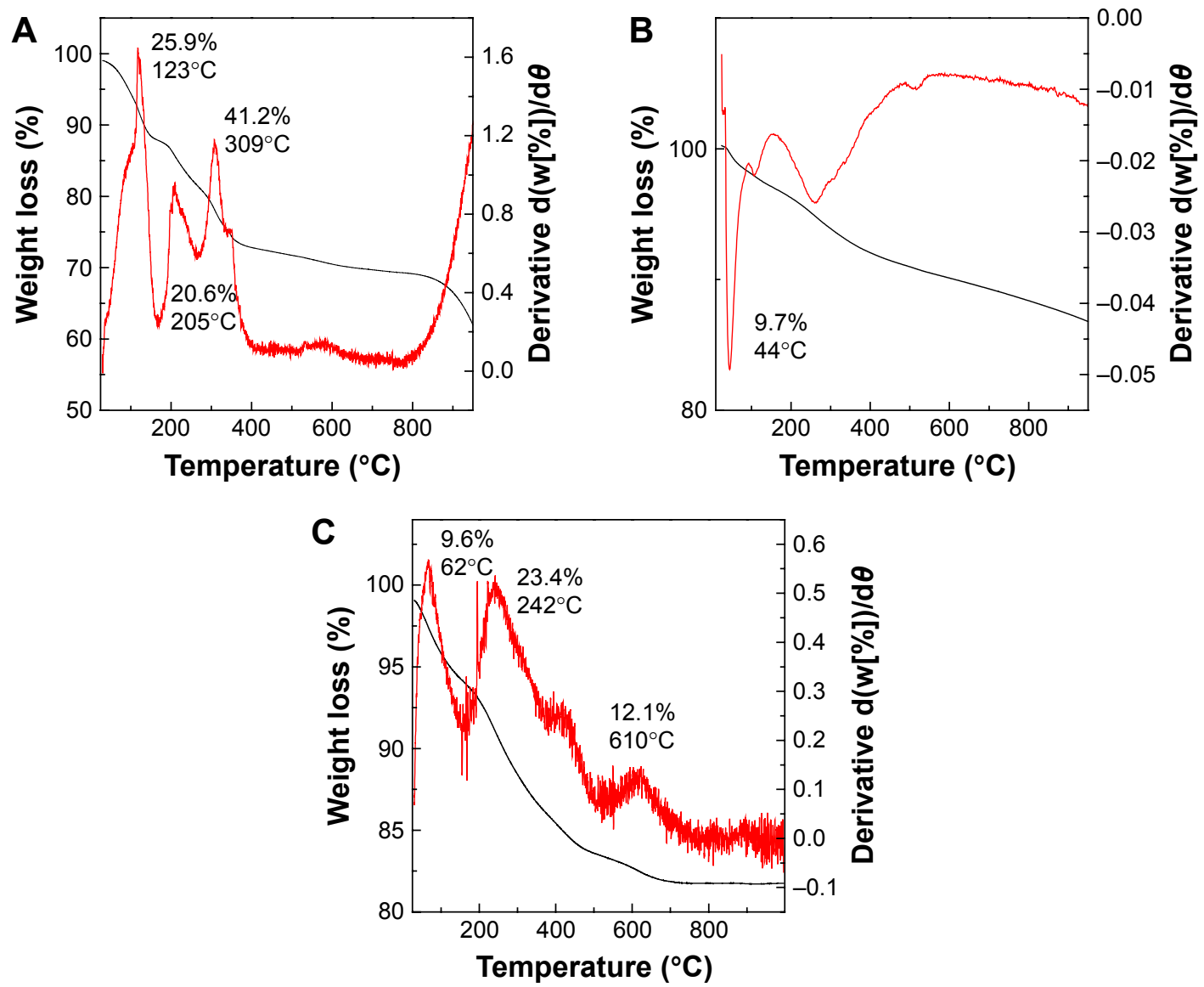

Figure 4 TGA/DTG thermograms of phytic acid sodium salt (A), iron oxide magnetic nanoparticles (B), and PTA-CS-MNP nanocomposite (C).

Abbreviations: PTA-CS-MNP, phytic acid-chitosan-iron oxide nanocomposite; TGA/DTG, thermogravimetric and differential thermogravimetric analyses.

PTA-CS-MNPs nanocomposite could be due to the existence of coated materials on the surface of MNPs and electron exchange between CS polymer coating and Fe atoms..$^{51-53}$ This could affect surface magnetic anisotropy and enhance surface spins disorientation. ${ }^{54}$

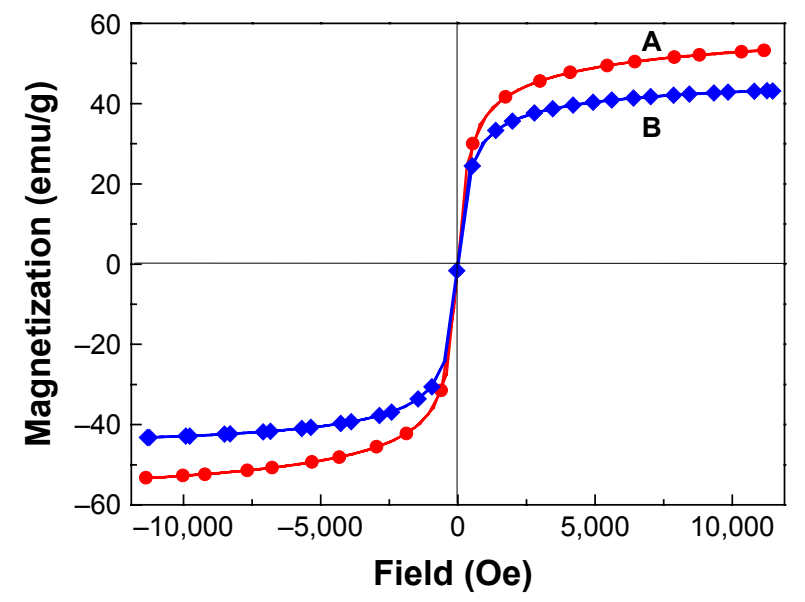

Figure 5 Magnetization curves of iron oxide magnetic nanoparticles (A) and phytic acid-loaded chitosan-iron oxide magnetic nanoparticles (B) recorded at room temperature.

Abbreviation: Oe, oersted.

\section{Determination of average size and size distribution properties}

Transmission electron microscopy images and size distribution of pristine $\mathrm{Fe}_{3} \mathrm{O}_{4}$, CS-MNPs, and PTA-CS-MNP nanocomposite are presented in Figure 6. The images show that nanosized particles were successfully prepared using coprecipitation method, and all the samples such as MNPs, CS-MNPs, and PTA-CS-MNP nanocomposite showed roughly spherical shape (Figure 6A-C). The average size of MNPs was $\sim 15 \pm 6 \mathrm{~nm}$ (Figure $6 \mathrm{D}$ ), whereas the mean sizes of CS-MNPs and PTA-CS-MNP nanocomposite were around $12 \pm 4 \mathrm{~nm}$ and $8 \pm 3 \mathrm{~nm}$, respectively (Figure 6E and F). The decrease in the size of CS-MNPs and PTA-CS-MNP nanocomposite after coating might be due to prolonged vigorous stirring at high speeds after adding CS and PTA. ${ }^{2}$

\section{In vitro release study of PTA from PTA-CS-MNP nanocomposite}

The UV-Vis absorption spectroscopy and calculations by calibration curve equation showed that the percentage 
A

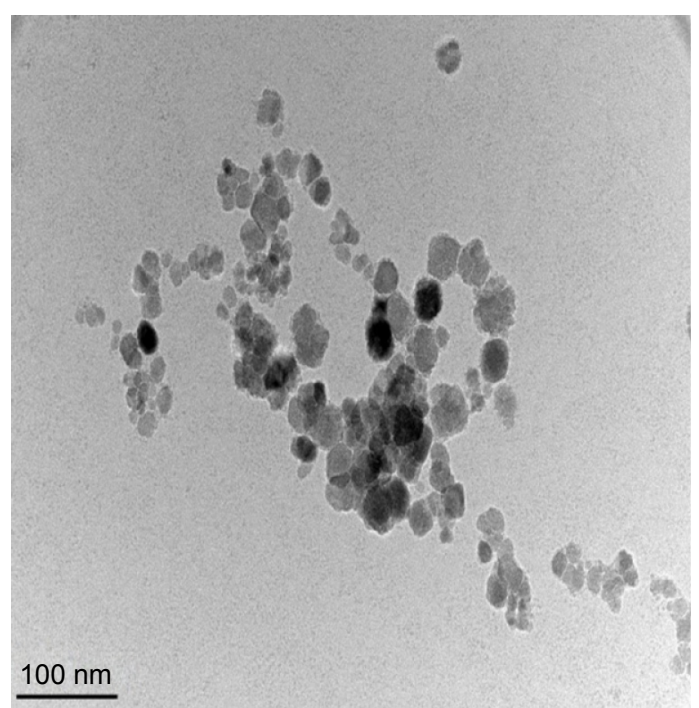

B

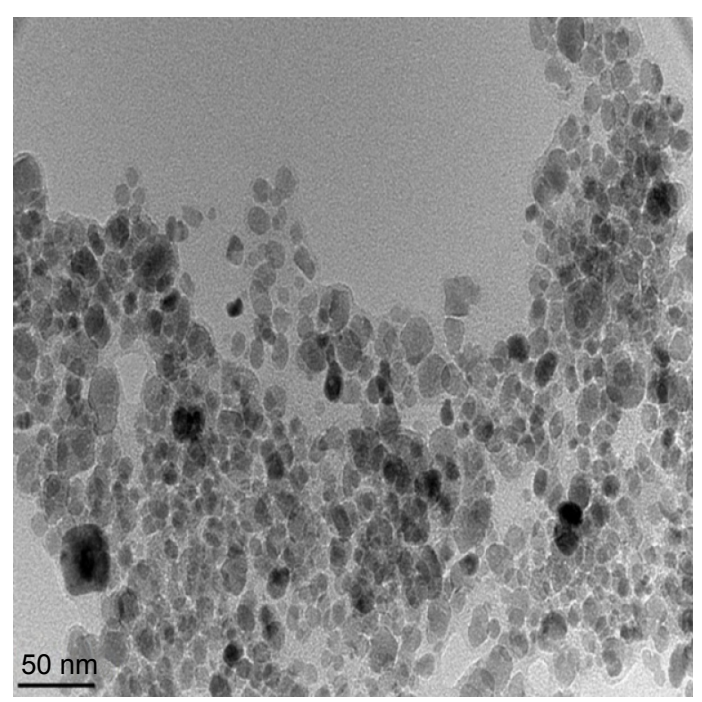

C

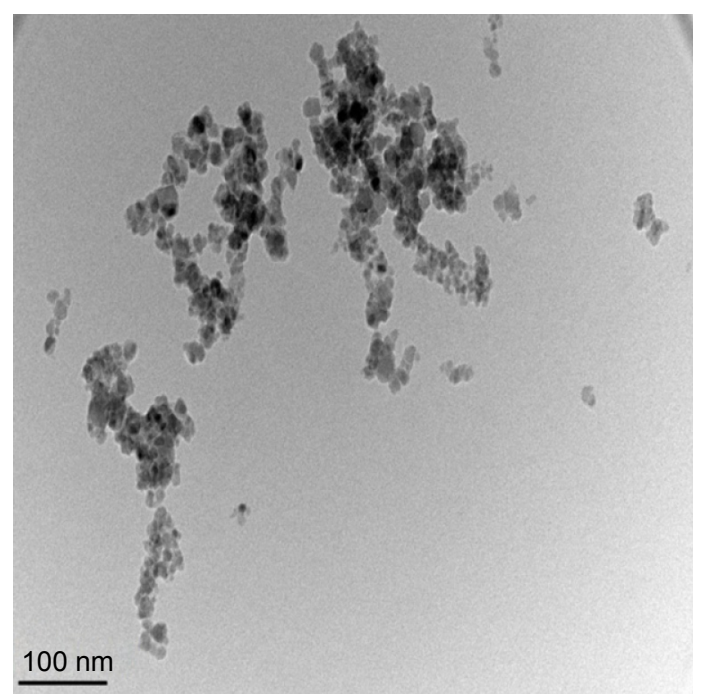

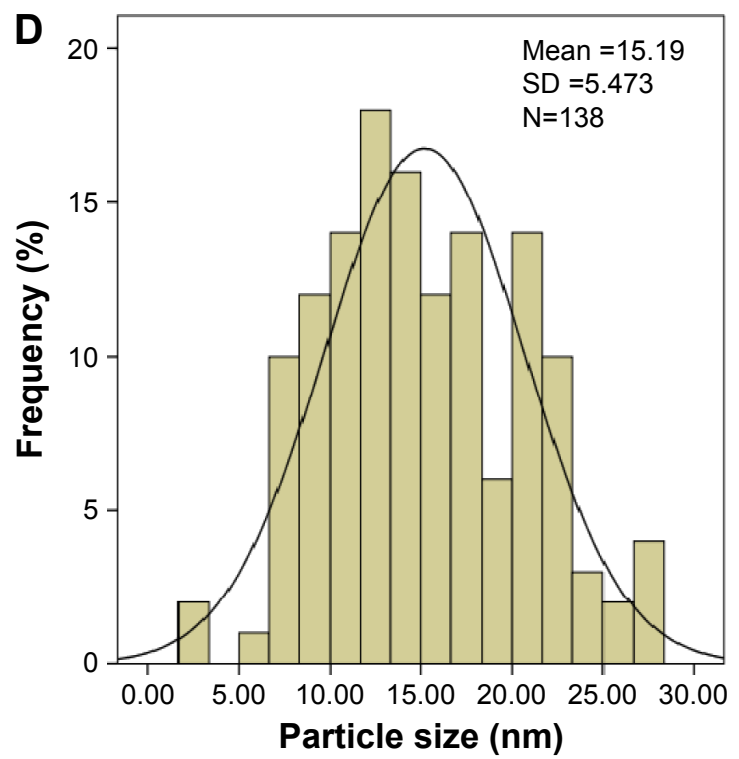

E
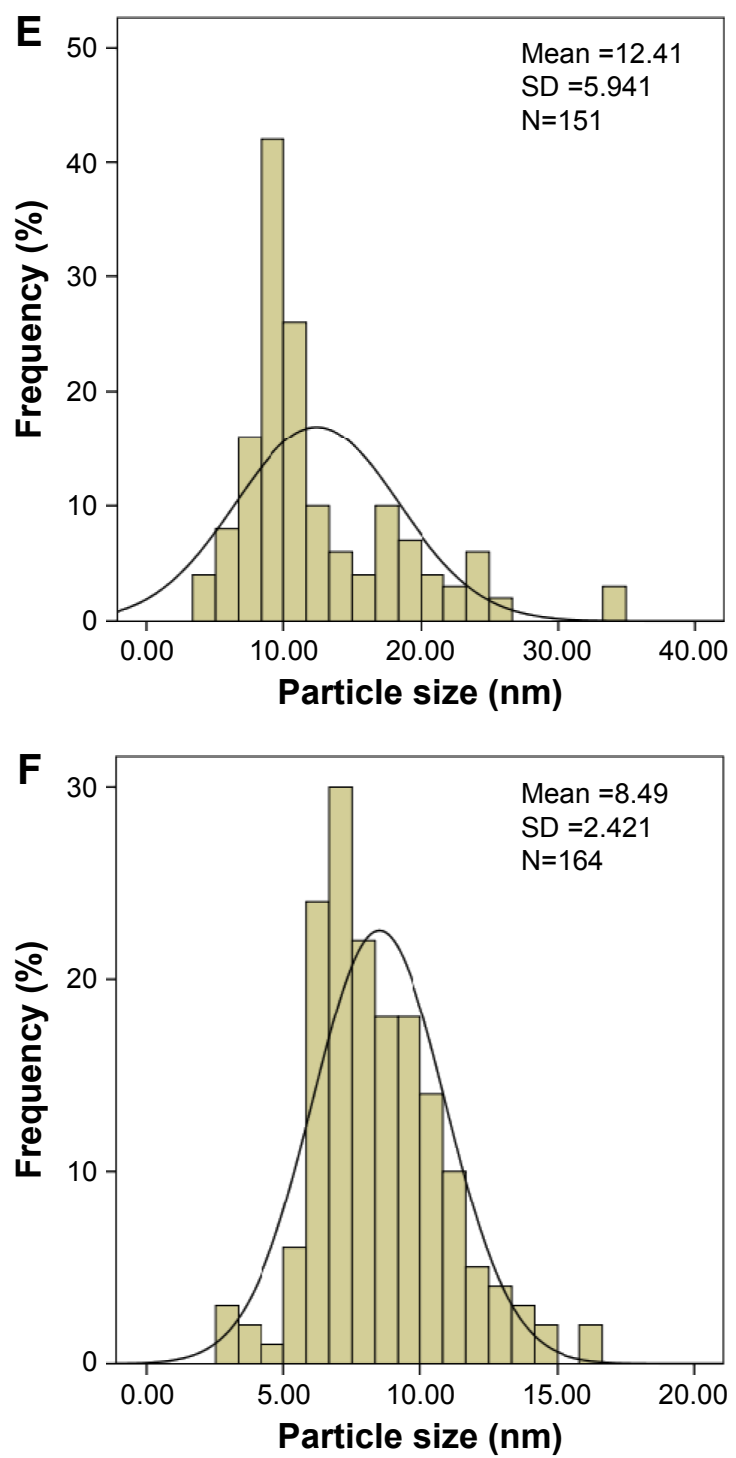

Figure 6 TEM micrographs of iron oxide magnetic nanoparticles (A), chitosan-iron oxide magnetic nanoparticles (B), and PTA-CS-MNP nanocomposite (C). Particle size distribution of iron oxide magnetic nanoparticles (D), chitosan-iron oxide magnetic nanoparticles (E), and PTA-CS-MNP nanocomposite (F). Abbreviations: PTA-CS-MNP, phytic acid-chitosan-iron oxide nanocomposite; TEM, transmission electron microscopy. 
loading of PTA in the PTA-CS-MNP nanocomposite was $12.9 \%$. The release profiles of PTA from the PTA-CS-MNP nanocomposite and physical mixture are shown in Figure 7. The physical mixture of PTA sodium salt with CS and MNPs exposed to $\mathrm{pH} 4.8$ or $\mathrm{pH} 7.4$ environment shows that the release of PTA was fast and completed within 60 seconds (inset in Figure 7). However, the release rate of PTA from the PTA-CS-MNP nanocomposite was markedly slower than that from the physical mixture, indicating that the PTA-CS-MNP nanocomposite is a potential controlled release drug-delivery system. This result may be attributed to the interaction between the negatively charged PTA and positively charged protonated CS.

The release rate of PTA from PTA-CS-MNP nanocomposite is dependent on the $\mathrm{pH}$ of the environment; the release rate of PTA at $\mathrm{pH} 7.4$ was remarkably lower than that at $\mathrm{pH} 4.8$. Figure 7 shows that the percent release of drug from nanocomposite reached 93\% within 56 hours when exposed to a $\mathrm{pH}$ environment of 4.8 and $86 \%$ by 127 hours at $\mathrm{pH} 7.4$ PBS.

Such a difference in the release rate at $\mathrm{pH} 4.8$ and 7.4 might be due to a possible difference in the release mechanism of PTA from the nanocomposite. At acidic $\mathrm{pH}$ ( $\mathrm{pH}$ 4.8), PTA-CS-MNP nanocomposite is unstable, but at $\mathrm{pH} 7.4$, it is more stable. ${ }^{55,56}$ As a result, the release would occur through ion exchange between PTA anions and negative anions available on the PBS.

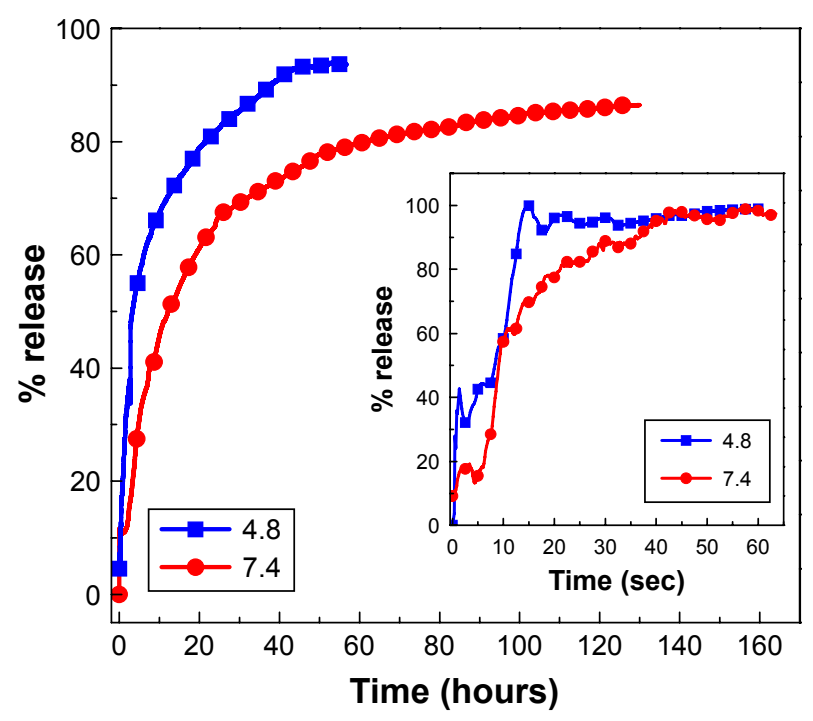

Figure 7 Release profiles of phytic acid from PTA-CS-MNP nanocomposite into phosphate-buffered saline solution at $\mathrm{pH} 7.4$ and $\mathrm{pH}$ 4.8. The inset shows the release profiles of a physical mixture of phytic acid sodium salt with chitosan and iron oxide nanoparticles into phosphate-buffered saline solution at $\mathrm{pH} 7.4$ and $\mathrm{pH} 4.8$. Abbreviation: PTA-CS-MNP, phytic acid-chitosan-iron oxide nanocomposite.

\section{Release kinetics of PTA from PTA-CS-MNP nanocomposite}

A number of kinetic models describe the total release of PTA from PTA-CS-MNP nanocomposite. The common models used include pseudo-first order, pseudo-second order, and parabolic diffusion models. Pseudo-first order kinetic equation is written as follows: ${ }^{57}$

$$
\operatorname{In}\left(\mathrm{q}_{\mathrm{e}}-\mathrm{q}_{\mathrm{t}}\right)=\operatorname{In} \mathrm{q}_{\mathrm{e}}-\mathrm{kt}
$$

where $\mathrm{q}_{\mathrm{e}}$ and $\mathrm{q}_{\mathrm{t}}$ are the equilibrium release amount and the release amount at time $\mathrm{t}$, respectively, and $\mathrm{k}$ is the constant of the corresponding release rate.

In pseudo-second order kinetic model, the release behavior of drugs from nanocomposite is described by the following equation: ${ }^{58}$

$$
\mathrm{t} / \mathrm{q}_{\mathrm{t}}=1 / \mathrm{kq}_{\mathrm{e}}^{2}+\mathrm{t} / \mathrm{q}_{\mathrm{e}}
$$

By plotting $t / \mathrm{q}_{\mathrm{t}}$ against $\mathrm{t}$, a straight line is obtained and the release rate constant $\mathrm{k}$, as well as $\mathrm{q}_{\mathrm{e}}$, can be calculated using a the following relation:

$$
\mathrm{k}=1 / \mathrm{q}_{\mathrm{e}}^{2} \cdot \text { intercept }
$$

The parabolic diffusion kinetic model is written as follows: ${ }^{59}$

$$
\frac{\left(1-\mathrm{M}_{\mathrm{t}} / \mathrm{M}_{\mathrm{o}}\right)}{\mathrm{t}}=\mathrm{kt}^{-0.5}+\mathrm{b}
$$

where $\mathrm{M}_{\mathrm{o}}$ and $\mathrm{M}_{\mathrm{t}}$ are the PTA content that remain in the nanocomposite at release time 0 and $t$, respectively.

Among these three kinetic models, it was found that the release kinetic processes of PTA from PTA-CS-MNP nanocomposite at $\mathrm{pH} 7.4$ and 4.8 were well governed by the pseudo-second order model, with correlation coefficients of $\left(R^{2}\right) 0.9996$ and 0.9980 and release rate constant $(\mathrm{k})$ values of $1.69 \times 10^{-5}$ and $2.86 \times 10^{-5} \mathrm{mg} / \mathrm{min}$, respectively (Figure 8 and Table 1).

The results of kinetic model gained in this work are similar to the release kinetic study of the chlorogenic acid intercalated into the $\mathrm{Zn} / \mathrm{Al}-\mathrm{LDH}, \mathrm{Mg} / \mathrm{Al}-\mathrm{LDH}$ by ionexchange and coprecipitation routes and $\mathrm{ZLH}^{58,60,61}$ and also very similar to release of protocatechuic acid from $\mathrm{Zn} / \mathrm{Al}$ layered double hydroxide and zinc layered hydroxide. ${ }^{62,63}$ 

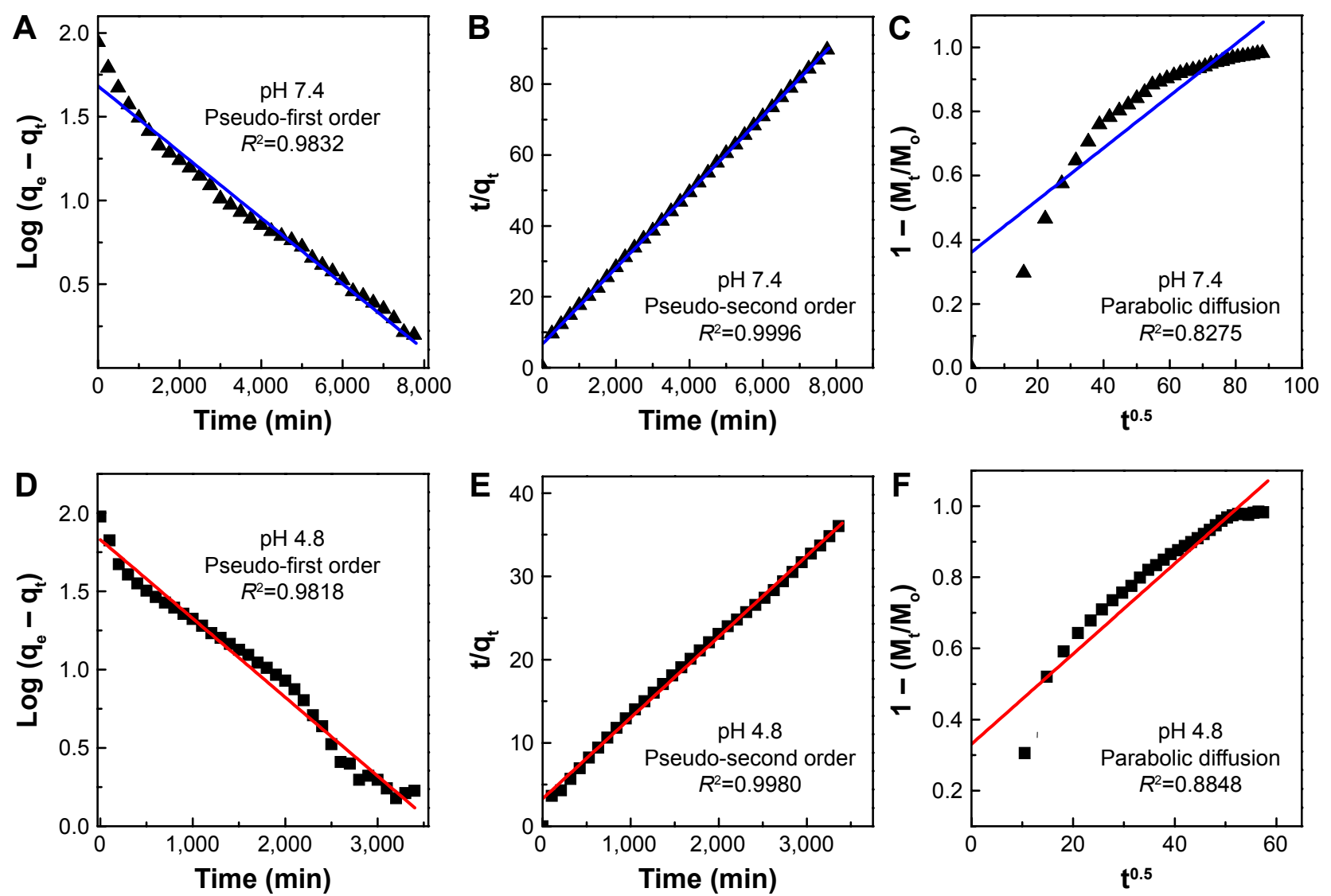

Figure 8 Fitting of the data for phytic acid release from PTA-CS-MNP nanocomposite into various solutions to the pseudo-first order, pseudo-second order kinetics and parabolic diffusion model for $\mathrm{pH} 7.4(\mathbf{A}-\mathbf{C})$ and $\mathrm{pH} 4.8$ (D-F).

Abbreviation: PTA-CS-MNP, phytic acid-chitosan-iron oxide nanocomposite.

\section{Cellular sensitivity of cells to PTA and PTA-CS-MNP nanocomposite}

The efficacy of PTA-CS-MNP nanocomposite in suppressing the growth of HT29 colorectal adenocarcinoma cells was assessed using colorimetric assay (MTT assay). The 3T3 normal fibroblast cells were employed as normal control to ensure the nontoxic nature of nanocomposite. As illustrated in Figure 9B, HT29 cells displayed a dose-dependent reduction in cell viability after 72 hours of incubation with nanocomposite. PTA-CS-MNP nanocomposite exerted a cytotoxic effect on HT29 at higher concentrations and showed a moderate inhibition at lower concentrations. In general, pure compound exhibited a much lower cytotoxic effect on HT29 cells with a higher half maximal inhibitory concentration value $\left(\mathrm{IC}_{50}\right.$ ) of $188.5 \mu \mathrm{g} / \mathrm{mL}$ compared to PTA-CSMNP nanocomposite, whose $\mathrm{IC}_{50}$ value was $45.63 \mu \mathrm{g} / \mathrm{mL}$. This shows that the introduction of CS-MNPs into PTA improved the efficacy of PTA in HT29 cells. It is apparent from Figure 9A that both free PTA and nanocomposite did not induce toxicity in 3T3 normal fibroblast cells. Both compounds did not affect cell viability in the tested range, as the survival was consistently greater than $80 \%$ or similar

Table I Correlation coefficient $\left(R^{2}\right)$, rate constant $(\mathrm{k})$, and half-life $\left(\mathrm{t}_{1 / 2}\right)$ values obtained by fitting the release data of phytic acid from PTA-CS-MNP nanocomposite into phosphate-buffered saline solution at $\mathrm{pH} 4.8$ and 7.4

\begin{tabular}{|c|c|c|c|c|c|c|}
\hline \multirow{2}{*}{$\begin{array}{l}\text { Aqueous } \\
\text { solution }\end{array}$} & \multirow{2}{*}{$\begin{array}{l}\text { Saturation } \\
\text { release (\%) }\end{array}$} & \multicolumn{3}{|l|}{$R^{2}$} & \multicolumn{2}{|c|}{ Pseudo-second order model } \\
\hline & & $\begin{array}{l}\text { Pseudo-first } \\
\text { order model }\end{array}$ & $\begin{array}{l}\text { Pseudo-second } \\
\text { order model }\end{array}$ & $\begin{array}{l}\text { Parabolic } \\
\text { diffusion }\end{array}$ & $\begin{array}{l}\text { Rate constant, } \\
\text { k (mg/min) }\end{array}$ & $\begin{array}{l}t_{1 / 2} \\
(\min )\end{array}$ \\
\hline $\mathrm{pH} 7.4$ & 86 & 0.9832 & 0.9996 & 0.8275 & $1.69 \times 10^{-5}$ & 630 \\
\hline $\mathrm{pH} 4.8$ & 93 & 0.9818 & 0.9980 & 0.8848 & $2.86 \times 10^{-5}$ & 339 \\
\hline
\end{tabular}

Abbreviation: PTA-CS-MNP, phytic acid-chitosan-iron oxide nanocomposite. 

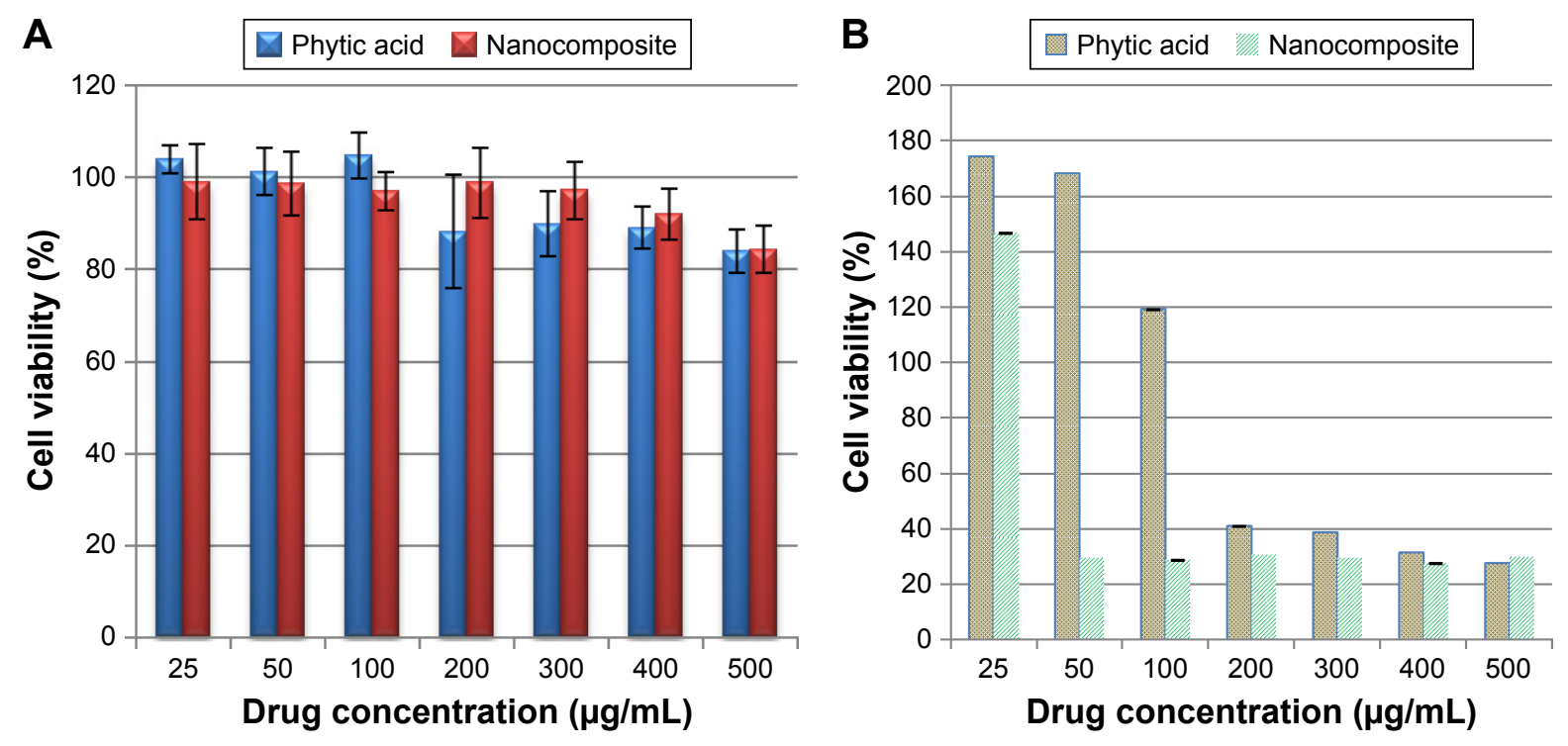

Figure 9 Cell viability (MTT assay) of 3 T3 (A) and HT29 (B) cells exposed to various gradient concentrations. The data are presented as mean \pm standard deviation of triplicate values.

Abbreviation: MTT, 3-(4,5-dimethylthiazol-2-yl)-2,5-diphenyltetrazolium bromide.

to control. In this case, it can be suggested that PTA-CSMNP nanocomposite possessed good anticancer activities when compared with pure compound PTA and demonstrated selectivity between cancerous and normal cells.

\section{Conclusion}

PTA-CS-MNP nanocomposite was successfully prepared by coating MNPs with CS and then loading it with PTA drug. The loading percentage of PTA into the nanocomposite was $12.9 \%$ and the superparamagnetic properties of PTA-CSMNP nanocomposite and MNPs were shown by vibrating sample magnetometry studies. The vibration modes of the coated CS to MNPs and loaded PTA, which supported the formation of PTA-CS-MNP nanocomposite, were confirmed by FTIR. The release profiles of the drug from nanocomposite into PBS were of sustained manner with total release equilibria of $86 \%$ and $93 \%$ when exposed to environments of $\mathrm{pH} 7.4$ and 4.8 at 127 and 56 hours, respectively. The pseudo-second order kinetics model was found to be the best fitting mathematical model. Overall, the findings of this study suggest that PTA-CS-MNP nanocomposites possess good anticancer potential against colon cancer cells and do not cause any cytotoxicity to normal fibroblast cells. Further, cellular and molecular studies are needed to find out the specific cellular mechanism that describes the specific action of nanocomposite against colon cancer cells. Also, in vivo studies are to be carried out to prove the therapeutic potential of the present tumor-specific delivery system.

\section{Acknowledgment}

We thank the Ministry of Science Technology and Innovation of Malaysia (MOSTI) for funding the project under grant No: 02-01-04-SF2141.

\section{Disclosure}

The authors report no conflicts of interest in this work.

\section{References}

1. Boisseau P, Loubaton B. Nanomedicine, nanotechnology in medicine. Comptes Rendus Physique. 2011;12(7):620-636.

2. Misra R, Acharya S, Sahoo SK. Cancer nanotechnology: application of nanotechnology in cancer therapy. Drug Discov Today. 2010;15(19-20): 842-850.

3. Nguyen TX, Huang L, Gauthier M, Yang G, Wang Q. Recent advances in liposome surface modification for oral drug delivery. Nanomedicine (Lond). 2016;11(9):1169-1185.

4. Li MH, Yu H, Wang TF, et al. Tamoxifen embedded in lipid bilayer improves the oncotarget of liposomal daunorubicin in vivo. J Mater Chem B. 2014;2(12):1619-1625.

5. Du D, Chang N, Sun S, et al. The role of glucose transporters in the distribution of p-aminophenyl- $\alpha$-d-mannopyranoside modified liposomes within mice brain. J Control Release. 2014;182:99-110.

6. Cao J, Wang R, Gao N, et al. A7RC peptide modified paclitaxel liposomes dually target breast cancer. Biomater Sci. 2015;3(12): 1545-1554.

7. Wang Q, Cheng H, Peng H, Zhou H, Li PY, Langer R. Non-genetic engineering of cells for drug delivery and cell-based therapy. Adv Drug Deliv Rev. 2015;91:125-140.

8. Peng H, Liu X, Wang G, et al. Polymeric multifunctional nanomaterials for theranostics. J Mater Chem B. 2015;3(34):6856-6870.

9. McCallion C, Burthem J, Rees-Unwin K, Golovanov A, Pluen A. Graphene in therapeutics delivery: problems, solutions and future opportunities. Eur J Pharm Biopharm. 2016;104:235-250.

10. Barahuie F, Saifullah B, Dorniani D, et al. Graphene oxide as a nanocarrier for controlled release and targeted delivery of an anticancer active agent, chlorogenic acid. Mater Sci Eng C. 2017;74:177-185. 
11. Kesharwani P, Jain K, Jain NK. Dendrimer as nanocarrier for drug delivery. Prog Polym Sci. 2014;39:268-307.

12. Peng $\mathrm{H}$, Wang $\mathrm{C}, \mathrm{Xu} \mathrm{X}$, Yu C, Wang Q. An intestinal Trojan horse for gene delivery. Nanoscale. 2015;7(10):4354-4360.

13. Barahuie F, Hussein MZ, Fakurazi S, Zainal Z. Development of drug delivery systems based on layered hydroxides for nanomedicine. Int $J$ Mol Sci. 2014;15(5):7750-7786.

14. Parsian M, Unsoy G, Mutlu P, Yalcin S, Tezcaner A, Gunduz U. Loading of Gemcitabine on chitosan magnetic nanoparticles increases the anti-cancer efficacy of the drug. Eur J Pharmacol. 2016;784: $121-128$.

15. Xiao Y, Lin ZT, Chen Y, et al. High molecular weight chitosan derivative polymeric micelles encapsulating superparamagnetic iron oxide for tumor-targeted magnetic resonance imaging. Int J Nanomedicine. 2015;10:1155-1172.

16. Zhao YB, Qiu ZM, Huang JY. Preparation and analysis of $\mathrm{Fe}_{3} \mathrm{O}_{4}$ magnetic nanoparticles used as targeted-drug carriers. Chinese J Chem Eng. 2008;16(3):451-455.

17. Ghotbi MY, bin Hussein MZ. Controlled release study of an anticarcinogenic agent, gallate from the surface of magnetite nanoparticles. J Phys Chem Solids. 2012;73(7):936-942.

18. Ahmad T, Rhee I, Hong S, Chang Y, Lee J. Ni- $\mathrm{Fe}_{2} \mathrm{O}_{4}$ nanoparticles as contrast agents for magnetic resonance imaging. J Nanosci Nanotechnol. 2011;11(7):5645-5650.

19. Laurent S, Forge D, Port M, et al. Magnetic iron oxide nanoparticles: synthesis, stabilization, vectorization, physicochemical characterizations, and biological applications. Chem Rev. 2008;108(6): 2064-2110.

20. Parveen S, Misra R, Sahoo SK. Nanoparticles: a boon to drug delivery, therapeutics, diagnostics and imaging. Nanomedicine. 2012;8(2): $147-166$.

21. Béalle G, Di Corato R, Kolosnjaj-Tabi J, et al. Ultra magnetic liposomes for MR imaging, targeting, and hyperthermia. Langmuir. 2012; 28(32):11834-11842.

22. Hirsch LR, Stafford RJ, Bankson JA, et al. Nanoshell-mediated nearinfrared thermal therapy of tumours under magnetic resonance guidance. Proc Natl Acad Sci U S A. 2003;100(23):13549-13554.

23. Qu J, Liu G, Wang Y, Hong R. Preparation of $\mathrm{Fe}_{3} \mathrm{O}_{4}$-chitosan nanoparticles used for hyperthermia. Adv Powder Technol. 2010;21(4): 461-467.

24. Denkbaş EB, Kiliçay E, Birlikseven C, Öztürk E. Magnetic chitosan microspheres: preparation and characterization. React Funct Polym. 2002;50(3):225-232.

25. Li GY, Jiang YR, Huang KL, Ding P, Chen J. Preparation and properties of magnetic $\mathrm{Fe}_{3} \mathrm{O}_{4}$-chitosan nanoparticles. J Alloys Compd. 2008; 466(1):451-456.

26. Artursson P, Lindmark T, Davis SS, Illum L. Effect of chitosan on the permeability of monolayers of intestinal epithelial cells (Caco-2). Pharm Res. 2004;11(9):1358-1361.

27. Hejazi R, Amiji M. Chitosan-based gastrointestinal delivery systems. J Control Release. 2003;89(2):151-165.

28. Miao Y, Tan SN. Amperometric hydrogen peroxide biosensor based on immobilization of peroxidase in chitosan matrix crosslinked with glutaraldehyde. Analyst. 2000;125(9):1591-1594.

29. Ravi Kumar MN. A review of chitin and chitosan applications. React Funct Polym. 2000;46(1):1-27.

30. Rabea EI, Badawy ME, Stevens CV, Smagghe G, Steurbaut W. Chitosan as antimicrobial agent: applications and mode of action. Biomacromolecules. 2003;4(6):1457-1465.

31. Hussein-Al-Ali SH, El Zowalaty ME, Hussein MZ, Geilich BM, Webster TJ. Synthesis, characterization, and antimicrobial activity of an ampicillin-conjugated magnetic nanoantibiotic for medical applications. Int J Nanomedicine. 2014;9:3801-3814.

32. Javid A, Ahmadian S, Saboury AA, Kalantar SM, Rezaei-Zarch S. Chitosan-coated superparamagnetic iron oxide nanoparticles for doxorubicin delivery: synthesis and anticancer effect against human ovarian cancer cells. Chem Biol Drug Des. 2013;82(3):296-306.
33. Canan C, Cruz FT, Delaroza F, et al. Studies on the extraction and purification of phytic acid from rice bran. J Food Comp Anal. 2011;24(7): 1057-1063.

34. Irshad M, Ahmad I, Mehdi SJ, Goel HC, Rizvi MM. Antioxidant capacity and phenolic content of the aqueous extract of commonly consumed cucurbits. Int J Food Prop. 2014;17(1):179-186.

35. Canan C, Delaroza F, Casagrande R, Baracat MM, Shimokomaki M, Ida EI. Antioxidant capacity of phytic acid purified from rice bran. Acta Sci Technol. 2012;34(4):457-463.

36. Tan BL, Norhaizan ME. Scientific evidence of rice by-products for cancer prevention: chemopreventive properties of waste products from rice milling on carcinogenesis in vitro and in vivo. Bio Med Res Int. 2017;2017:9017902.

37. Henderson AJ, Ollila CA, Kumar A, et al. Chemopreventive properties of dietary rice bran: current status and future prospects. Adv Nutr. 2012;3:643-653.

38. Norhaizan ME, Ng SK, Norashareena MS, Abdah MA. Antioxidant and cytotoxicity effect of rice bran phytic acid as an anticancer agent on ovarian, breast and liver cancer cell lines. Malays J Nutr. 2011;17(3): $367-375$.

39. Norazalina S, Norhaizan ME, Hairuszah I, Norashareena MS. Anticarcinogenic efficacy of phytic acid extracted from rice bran on azoxymethaneinduced colon carcinogenesis in rats. Exp Toxicol Pathol. 2010; 62(3):259-268.

40. Al-Fatlawi AA, Rizvi MM, Ahmad A. Anticarcinogenic activity of rice bran phytic acid against human breast cancer cell line (mcf-7). Asian J Pharm Clin Res. 2014;7(1):151-155.

41. Lee H, Shao H, Huang Y, Kwak B. Synthesis of MRI contrast agent by coating superparamagnetic iron oxide with chitosan. IEEE Trans Magn. 2005;41(10):4102-4104.

42. Calmon MF, de Souza AT, Candido NM, et al. A systematic study of transfection efficiency and cytotoxicity in HeLa cells using iron oxide nanoparticles prepared with organic and inorganic bases. Colloids Surf B Biointerfaces. 2012;100:177-184.

43. Dodi G, Hritcu D, Lisa G, Popa MI. Core-shell magnetic chitosan particles functionalized by grafting: synthesis and characterization. Chem Eng J. 2012;203:130-141.

44. Unsoy G, Yalcin S, Khodadust R, Gunduz G, Gunduz U. Synthesis optimization and characterization of chitosan-coated iron oxide nanoparticles produced for biomedical applications. J Nanopart Res. 2012; 14(11):964.

45. Marchessault RH, Ravenelle F, Zhu XX, editors. Polysaccharides for Drug Delivery and Pharmaceutical Applications. Vol 934. Washington, DC: American Chemical Society; 2006.

46. Saburov KA, Kamilov KM. Structure of phytic acid and phytates. Chem Nat Compd. 1989;25(6):695-698.

47. Qu JB, Shao HH, Jing GL, Huang F. PEG-chitosan-coated iron oxide nanoparticles with high saturated magnetization as carriers of 10-hydroxycamptothecin: preparation, characterization and cytotoxicity studies. Colloids Surf B Biointerfaces. 2013;102:37-44.

48. Hussein-Al-Ali SH, El Zowalaty ME, Hussein MZ, Ismail M, Webster TJ. Synthesis, characterization, controlled release, and antibacterial studies of a novel streptomycin chitosan magnetic nanoantibiotic. Int J Nanomedicine. 2014;9:549-557.

49. Daneluti AL, Velasco MV, Baby AR, Matos JD. Thermal behavior and free-radical-scavenging activity of phytic acid alone and incorporated in cosmetic emulsions. Cosmetics. 2015;2(3):248-258.

50. Kayal S, Ramanujan RV. Doxorubicin loaded PVA coated iron oxide nanoparticles for targeted drug delivery. Mater Sci Eng C. 2010;30(3): 484-490.

51. Kumar R, Inbaraj BS, Chen BH. Surface modification of superparamagnetic iron nanoparticles with calcium salt of poly $(\gamma$-glutamic acid) as coating material. Mater Res Bull. 2010;45(11): 1603-1607.

52. Yu S, Chow GM. Carboxyl group $\left(-\mathrm{CO}_{2} \mathrm{H}\right)$ functionalized ferrimagnetic iron oxide nanoparticles for potential bio-applications. J Mater Chem. 2004;14(18):2781-2786. 
53. Shan Z, Yang WS, Zhang X, Huang QM, Ye H. Preparation and characterization of carboxyl-group functionalized superparamagnetic nanoparticles and the potential for bio-applications. J Braz Chem Soc. 2007;18(7):1329-1335.

54. Ge Y, Zhang Y, Xia J, et al. Effect of surface charge and agglomerate degree of magnetic iron oxide nanoparticles on $\mathrm{KB}$ cellular uptake in vitro. Colloids Surf B Biointerfaces. 2009;73(2):294-301.

55. Barahuie F, Hussein MZ, Hussein-Al-Ali SH, Arulselvan P, Fakurazi S, Zainal Z. Preparation and controlled-release studies of protocatechuic acid-magnesium/aluminium-layered double hydroxide nanocomposite. Int J Nanomedicine. 2013;8:1975-1987.

56. Khan AI, O'Hare D. Intercalation chemistry of layered double hydroxides: recent developments and applications. J Mater Chem. 2002; 12(11):3191-3198.

57. Dong L, Yan L, Hou WG, Liu SJ. Synthesis and release behavior of composites of camptothecin and layered double hydroxide. J Solid State Chem. 2010;183(8):1811-1816.

58. Barahuie F, Hussein MZ, Arulselvan P, Fakurazi S, Zainal Z. Development of the anticancer potential of a chlorogenate-zinc layered hydroxide nanohybrid with controlled release property against various cancer cells. Sci Adv Mater. 2013;5(12):1983-1993.
59. Ho YS, Ofomaja AE. Pseudo-second-order model for lead ion sorption from aqueous solutions onto palm kernel fiber. J Hazard Mater. 2006; 129(1-3):137-142.

60. Barahuie F, Hussein MZ, Arulselvan P, Fakurazi S, Zainal Z. Drug delivery system for an anticancer agent, chlorogenate-Zn/Al-layered double hydroxide nanohybrid synthesised using direct co-precipitation and ion exchange methods. J Solid State Chem. 2014;217:31-41.

61. Barahuie F, Hussein MZ, Arulselvan P, Fakurazi S, Zainal Z. Controlled in vitro release of the anticancer drug chlorogenic acid using magnesium/aluminium-layered double hydroxide as a nanomatrix. Sci Adv Mater. 2016;8(3):501-513.

62. Barahuie F, Hussein MZ, Abd Gani S, Fakurazi S, Zainal Z. Synthesis of protocatechuic acid-zinc/aluminium layered double hydroxide nanocomposite as an anticancer nanodelivery system. J Solid State Chem. 2015;221:21-31.

63. Barahuie F, Hussein MZ, Abd Gani S, Fakurazi S, Zainal Z. Anticancer nanodelivery system with controlled release property based on protocatechuate-zinc layered hydroxide nanohybrid. Int J Nanomedicine. 2014;9:3137-3149.
International Journal of Nanomedicine

\section{Publish your work in this journal}

The International Journal of Nanomedicine is an international, peerreviewed journal focusing on the application of nanotechnology in diagnostics, therapeutics, and drug delivery systems throughout the biomedical field. This journal is indexed on PubMed Central, MedLine, CAS, SciSearch $\AA$, Current Contents ${ }^{\circledR} /$ Clinical Medicine,

\section{Dovepress}

Journal Citation Reports/Science Edition, EMBase, Scopus and the Elsevier Bibliographic databases. The manuscript management system is completely online and includes a very quick and fair peer-review system, which is all easy to use. Visit http://www.dovepress.com/ testimonials.php to read real quotes from published authors. 